\title{
Effects of different five-day progesterone-based synchronization protocols on the estrous response and follicular/luteal dynamics in dairy cows
}

\author{
Fernando LÓPEZ-GATIUS ${ }^{1,2)}$, Irene LÓPEZ-HELGUERA ${ }^{1)}$, Fabio DE RENSIS ${ }^{3)}$ and \\ Irina GARCIA-ISPIERTO ${ }^{1,2)}$ \\ 1) Agrotecnio Centre, University of Lleida, Lleida 25198, Spain \\ ${ }^{2)}$ Department of Animal Production, University of Lleida, Lleida 25198, Spain \\ ${ }^{3)}$ Department of Food Science, University of Parma, Parma 43121, Italy
}

\begin{abstract}
This study compared the responses shown by lactating dairy cows to four different P4-based protocols for AI at estrus. Cows with no estrous signs $96 \mathrm{~h}$ after progesterone intravaginal device (PRID) removal were subjected to fixed-time AI (FTAI), and their data were also included in the study. In Experiment I, follicular/luteal and endometrial dynamics were assessed every $12 \mathrm{~h}$ from the beginning of treatment until AI. The estrous response was examined in Experiment II, and fertility was assessed in both experiments. The protocols consisted of a PRID fitted for five days, along with the administration of different combinations of gonadotropin releasing hormone $(\mathrm{GnRH})$, equine chorionic gonadotropin and a single or double dose (24 h apart) of prostaglandin $\mathrm{F}_{2 \alpha}$. In Experiment I (40 cows), animals receiving GnRH at the start of treatment showed a significantly higher ovulation rate during the PRID insertion period while estrus was delayed. In Experiment II (351 cows), according to the odds ratios, cows showing luteal activity at the time of treatment were less likely to show estrus than cows with no signs of luteal activity. Treatment affected the estrous response and the interval from PRID removal to estrus but did not affect conception rates 28-34 days post AI. Primiparous cows displayed a better estrous response than multiparous cows. Our findings reveal acceptable results of 5-day P4-based protocols for AI at estrus in high-producing dairy cows. Time from treatment to estrus emerged as a good guide for FTAI after a 5-day P4-based synchronization protocol.
\end{abstract}

Key words: Bovine, eCG, Fertility, Pedometers

(J. Reprod. Dev. 61: 465-471, 2015)

l: $\mathrm{n}$ the past few decades, high-producing dairy herds have suffered a rise in reproductive disorders and a decline in fertility linked to numerous factors $[1,2]$ besides increased milk production [3-5]. The health and fertility of dairy cows has been improved through new management practices that pursue animal well-being [6], and this has meant a higher level of management in high-producing compared with lower-producing herds [7]. However, both the high incidence of cows suffering anestrus [8] and the poor detection of estrus [9] remain major concerns in dairy herds and are cogent reasons why breeding synchronization protocols for fixed-time insemination (FTAI) have become routine components of the reproductive management of lactating cows.

Ovulation and estrus can be induced by progesterone (P4) treatment (for 7-9 days) in combination with gonadotropin releasing hormone $(\mathrm{GnRH})$ or an analog and prostaglandin $\mathrm{F}_{2 \alpha}\left(\mathrm{PGF}_{2 \alpha}\right)$ or an analog [10-13]. Progesterone-based protocols allow for effective FTAI in lactating dairy cows, regardless of whether cows are cyclic or

Received: April 25, 2015

Accepted: June 27, 2015

Published online in J-STAGE: July 24, 2015

(C)2015 by the Society for Reproduction and Development

Correspondence: F López-Gatius (e-mail: flopez@prodan.udl.cat)

This is an open-access article distributed under the terms of the Creative

Commons Attribution Non-Commercial No Derivatives (by-nc-nd) License

$<$ http://creativecommons.org/licenses/by-nc-nd/3.0/>. noncyclic (anestrous cows) and without the need to detect estrus [14-16]. Five-day P4-based protocols have provided results that compare favorably with those observed for longer protocols [17-19]. Briefly, Lima et al. [17] questioned the administration of GnRH on the first day of the protocol when animals received a single dose of prostaglandin $\mathrm{F}_{2 \alpha}\left(\mathrm{PGF}_{2 \alpha}\right) 5$ days later. Ribeiro et al. [18] increased the number of pregnancies per AI by administering twice the luteolytic dose of $\mathrm{PGF}_{2 \alpha}$ given $24 \mathrm{~h}$ apart at $\mathrm{P} 4$-device removal in presynchronized lactating cows. Finally, Garcia-Ispierto et al. [19] improved fertility on spontaneous estrus by adding eCG at P4-device removal in high-producing dairy cows under heat stress.

The success of five-day P4-based protocols is probably due to the conversion of younger, healthier oocytes into follicles with a shorter dominance life than longer protocols [20-22]. These shorter estrus synchronization protocols make use of different combinations of hormones such as GnRH, equine chorionic gonadotropin (eCG) and/ or $\mathrm{PGF}_{2 \alpha}$ given as two luteolytic doses $24 \mathrm{~h}$ apart upon P4-device removal. The role of each hormonal drug and intervals between the drugs used in each protocol could depend on the cyclicity status of the cow. To clarify the effectiveness of different five-day P4-based protocols in a recent study [23], we assessed the following in cycling and non-cycling lactating dairy cows: follicular and luteal dynamics (at treatment and $\mathrm{AI}$ and at 10 days after $\mathrm{AI}$ ) and fertility in response to four 5-day P4-based protocols for FTAI, including the most representative different hormone combinations described in the 
literature. Thus, the effects of GnRH (on the first day of the protocol) and eCG (on P4 device removal) and the effects of a single or double dose (given $24 \mathrm{~h}$ apart) of $\mathrm{PGF}_{2 \alpha}$ upon $\mathrm{P} 4$ device removal were examined. All four protocols tested were able to induce ovulation in both cyclic and noncyclic animals such that FTAI returned a pregnancy rate similar to that for spontaneous estrus. The results of this study [23] furthermore suggested that the ovarian response and fertility resulting from each treatment were due more to the ovarian structures present at the time of treatment than to the different combinations of hormones investigated. Therefore, differences in estrous response for the different protocols should be expected so that FTAI can be better adjusted for each protocol. Aiming to improve FTAI with five-day P4-based protocols, this study compared the effects of the four protocols examined previously [23] on follicular/luteal and endometrial dynamics, assessed every $12 \mathrm{~h}$ from treatment onset until AI (Experiment I), and the estrous response (Experiment II) in lactating dairy cows. Fertility was assessed in both experiments.

\section{Materials and Methods}

\section{Cattle and herd management}

The study was performed on two well-managed, high-producing, commercial Holstein-Friesian dairy herds in northeastern Spain. The mean numbers of lactating cows in the herds were 825 (Herd 1) and 1825 (Herd 2) during the study period (April 2013 to May 2014). The mean annual culling rate was $28 \%$. Mean annual milk production for the herds during the study period was $12,528 \mathrm{~kg}$ per cow. The cows were grouped according to age (primiparous $v s$. multiparous), milked three times daily and fed complete rations. Dry cows were kept in a separate group and transferred to a "parturition group" 7-25 days before parturition depending on their body condition score [24, 25] and if they carried twins [26]. An early postpartum, or "fresh cow," group was established for postpartum daily checks and nutrition controls 7 to 20 days postpartum. All cows were artificially inseminated. Although estrus detection started on day 14 postpartum, the voluntary waiting period for the herd was 50 days.

\section{Reproductive health management}

In the postpartum daily checks, the following puerperal diseases were treated until resolved or until culling: signs of injury to the genital area (i.e., vaginal or recto-vulvar lacerations), metabolic diseases such as hypocalcemia and ketosis (for the latter, diagnosed during the first or second week postpartum), retained placenta (fetal membranes retained longer than $12 \mathrm{~h}$ after parturition) and puerperal metritis (diagnosed during the first or second week postpartum in cows not suffering placenta retention).

The herd was maintained on a weekly reproductive health program. This involved examining the reproductive tract of each animal by ultrasound from 15 to 21 days postpartum to check for normal uterine involution and ovarian structures. Reproductive disorders diagnosed at this time such as endometritis or ovarian cysts were treated until resolved. Detectable cloudy intrauterine fluid was interpreted as endometritis [27]. An ovarian cyst was diagnosed when a follicular structure larger than $20 \mathrm{~mm}$ in diameter (external diameter including the wall) was detected in either or both ovaries in the absence of a corpus luteum (CL) and uterine tone [28]. A second exam was performed to check uterine and ovarian structures at the end of the voluntary waiting period on days $40-46$ postpartum. Possible endometritis and/or ovarian cysts were also recorded and treated at this time. In the latter exam, a cow was recorded as suffering follicular anovulation when a follicular structure of at least 8-15 $\mathrm{mm}$ was detected in two consecutive examinations in the absence of a CL or cyst and when no estrous signs were noted during the 7-day period between the exams [14].

Since a retained placenta or puerperal metritis has been related to subsequent pregnancy loss in cows [29], both disorders were always treated by introducing oxytetracycline boluses into the uterus and administering cefquinome sulfate i.m. and then administering $\mathrm{PGF}_{2 \alpha}$ at the end of treatment. Prostaglandin $\mathrm{F}_{2 \alpha}$ or a synthetic analog was also used to treat pyometra and ovarian cysts. In the latter case, treatment was subsequent to manual rupture of the cystic structure per rectum [30]. Cows suffering follicular anovulation received a progesterone-based treatment [16].

\section{Detection of estrus, insemination and pregnancy diagnosis}

Estrus was detected using a pedometer system (AfiFarm System; SAE Afikim). Walking activity values were recorded at the milking parlor (three times daily) and analyzed automatically using a herd management computer program. A walking activity greater than $80 \%$ of the mean activity recorded in the previous 2 days was taken as the lower limit for a cow to be considered in estrus. Since this herd was observed in a previous study to show a very significant positive relationship between increased walking activity and fertility provided this increase was $80 \%$ to $993 \%$ [31], values lower than $80 \%$ were not considered as estrus signs. Prior individual information concerning estrus detection was also taken into account. For example, if a cow normally showed a $400 \%$ increase in activity but showed an increase of around $120 \%$ during its two last estrus periods, the cow was explored for possible conditions other than estrus such as acute lameness or a change in location.

All cows were artificially inseminated using semen from bulls of proven fertility. Estrus was confirmed by palpation per rectum $[32,33]$ in cows deemed to be in estrus using the pedometer system described above, and the animals were inseminated at this time. Only cows showing estrous signs with strong uterine contractility (determined by uterine tone) and copious transparent vaginal fluid were inseminated $[9,34]$. If a cow returned to estrus, its status was confirmed by examination per rectum, and the animal was recorded as nonpregnant. In the remaining cows, pregnancy diagnosis was performed by ultrasound at 28-34 days post AI.

\section{Experimental design}

All procedures were approved by the Ethics Committee on Animal Experimentation of the University of Lleida (license numbers CEEA.09-01/12 and CEEA.09-01/13).

During the weekly reproductive visit, open cows more than 60 days in milk with no estrous signs for at least 21 days and no reproductive disorders such as ovarian cysts or endometritis detected by ultrasound were randomly assigned to one of the following groups: 2PGG, 2PGGe, 2PGe and PGe (Fig. 1). Cows in the 2PGG group were treated with a progesterone-releasing intravaginal device (PRID) (PRID DELTA, containing $1.55 \mathrm{~g}$ of progesterone; CEVA Salud 


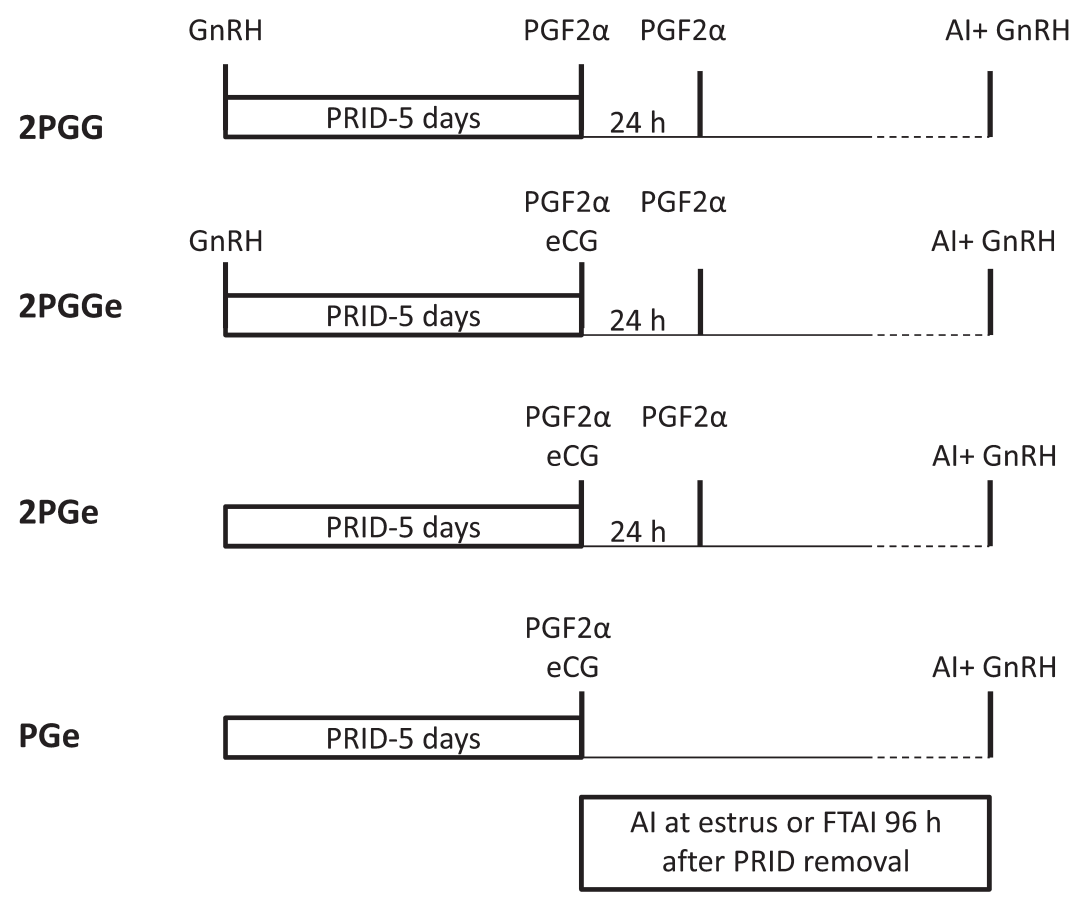

Fig. 1. Treatment protocols used to synchronize estrus for AI at estrus or for fixed-time AI (FTAI) $96 \mathrm{~h}$ after progesterone releasing intravaginal device (PRID) removal in high-producing dairy cows. All cows were fitted with a PRID (PRID DELTA, containing $1.55 \mathrm{~g}$ of progesterone; CEVA Salud Animal, Barcelona, Spain) for 5 days and received a GnRH dose at AI. Experiment I (40 cows): individual follicles $>8 \mathrm{~mm}$ and CLs $>10 \mathrm{~mm}$ were recorded from day 0 to AI every $12 \mathrm{~h}$; the uterine horns were scanned every $12 \mathrm{~h}$ from PRID removal to AI to determine the presence of hypoechoic or dark areas of the endometrium; and blood samples for P4 determination were obtained in a subset of 28 cows. Experiment II (351 cows): luteal structures were recorded at the beginning of the treatment.

Animal, Barcelona, Spain) plus GnRH (100 $\mu \mathrm{g}$ i.m.; Cystoreline, CEVA Santé Animale, Libourne, France) upon PRID insertion. The PRID was left for 5 days, and these animals were also given $\mathrm{PGF}_{2 \alpha}$ (25 mg dinoprost i.m.; Enzaprost, CEVA Santé Animale) on PRID removal. Twenty-four hours later, the cows received a second PGF2 $\alpha$ dose and were inseminated, and they received a second GnRH dose either at estrus (cows showing estrus) or $96 \mathrm{~h}$ after PRID removal (FTAI: cows with no estrous signs). Cows with no estrous signs 96 $\mathrm{h}$ after PRID removal were subjected to FTAI, and their data were also included in the study. The remaining groups were treated with the same P4-based protocol but with the following differences: cows in the 2PGGe group received $500 \mathrm{IU}$ of eCG i.m. (Syncostim, CEVA Santé Animale) on PRID removal; cows in 2PGe received eCG on PRID removal and no GnRH on PRID insertion; and cows in the PGe group received eCG on PRID removal, no GnRH on PRID insertion and no second dose of $\mathrm{PGF}_{2 \alpha}$. Only healthy cows with no signs of mastitis, lameness or digestive disorders were included in the study. Two experiments were performed, one to investigate the effects of treatments on follicular/luteal/endometrial dynamics (Experiment I) and one to investigate the estrous response (Experiment II). Fertility was assessed in both experiments.

Cows diagnosed as not pregnant received no further treatment. This meant that a cow entered in a five-day P4-based protocol was included only once in both experiments.
Experiment I. Effects of four different P4-based estrus synchronization protocols on follicular/luteal/endometrial dynamics

This experiment was designed to establish the possible effects of each treatment on follicular/luteal/endometrial dynamics. The data examined were derived from 40 lactating Holstein-Friesian cows in Herd 1 for the period April to May 2013. All cows were inseminated by the same technician using semen from a single bull. All gynecological exams and pregnancy diagnoses were performed by the second author.

The ovaries were examined by real-time (no video tapes) transrectal ultrasonography. The ultrasound machine was equipped with a 7.5 $\mathrm{MHz}$ linear array transducer. Individual follicles $>8 \mathrm{~mm}$ and CLs $>10 \mathrm{~mm}$ were identified sequentially from day 0 to AI every $12 \mathrm{~h}$ (Fig. 1) as previously described [35]. The location of each structure was determined in two planes, the craniocaudal and mediolateral planes, by positioning the transducer over an ovary and rotating the transducer around its long axis. Follicle diameter was measured using the internal calipers of the ultrasound machine, and CL size was estimated by averaging the longest and widest measured points of the structure. In each examination, the ovary was sketched in the two planes to show the relative location and size of the structures. Also follicle size was determined without reference to records in each examination except the first, and the positions of individual follicles were compared with the sketch from the previous examination. In 
this manner, individual follicles that were identifiable were given a letter code, which was maintained for as long as the follicle diameter remained $\geq 8 \mathrm{~mm}$.

From PRID removal to AI, the uterine horns were scanned every $12 \mathrm{~h}$ to determine the presence of hypoechoic or dark areas of the endometrium, including anechoic intrauterine fluid (IUF), as an indicator of estrus [36]. In a subset of cows $(n=28)$, blood samples were collected from the coccygeal vein into heparinized vacuum tubes (BD Vacutainer ${ }^{\mathrm{TM}}$, Becton, Dickinson and Company, Plymouth, UK) immediately before an ultrasound exam. Progesterone concentrations were determined in plasma using an enzyme-linked immunosorbent assay (ELISA) (Ridgeway Science, Alvington, Gloucestershire, UK). The sensitivity of the assay was $0.15 \mathrm{ng} / \mathrm{ml}$.

The following data were recorded for each animal: parturition and treatment dates; parity (primiparous vs. multiparous); treatment (2PGG, 2PGGe, 2PGe or PGe); milk production at treatment (mean production during the three days before treatment) (low producers $<40 \mathrm{~kg}$ versus high producers $\geq 40 \mathrm{~kg}$ ); days in milk at treatment (DIM; $<90$ days postpartum $v s . \geq 90$ days postpartum); cyclicity at treatment (CY: presence of at least one CL); ovulation after PRID insertion (disappearance of a follicular structure larger than $8 \mathrm{~mm}$ associated with the development of a young CL 24-48 h later in the same location); follicular dynamics after PRID insertion (appearance or disappearance of a follicular structure larger than $10 \mathrm{~mm}$ before PRID removal); follicular structures on PRID removal (presence or absence of at least a follicle $>10 \mathrm{~mm}$ in diameter); plasma progesterone concentrations on PRID removal and 12, 24, 36, 48, 60, 72, 84 and $96 \mathrm{~h}$ later; luteal structures at AI (presence vs absence of at least one CL); diameter of the largest follicle at AI (continuous variable); uterine indicators of estrus (presence vs absence); estrus detection after PRID removal (presence vs absence); hours from PRID removal to AI (continuous variable); and conception rate 28-34 days post AI.

All categorical variables were analyzed by Tukey-Kramer tests, and continuous variables were analyzed by analysis of variance (ANOVA) and Tukey post hoc tests using the logistic procedure. The effects of treatment on the interval (h) from PRID removal to AI were assessed by ANOVA and Tukey post hoc tests using the logistic procedure of PASW Statistics for Windows Version 18.0 (SPSS, Chicago, IL, USA). The effects of treatment on progesterone concentrations after PRID removal were determined by general linear model repeated measures ANOVA. Significance was set at $\mathrm{P}<0.05$.

\section{Experiment II. Effects of the four different P4-based estrus synchronization protocols on estrus detection and the conception rate}

Since a clear effect of treatment on time from PRID removal to estrus was observed in Experiment I, Experiment II was designed to evaluate the effects of each treatment on the estrous response and fertility in a larger study population including 257 and 94 cows from Herds 1 and 2, respectively, for the period of June 2013 through May 2014. The data recorded for each animal were the same as those for Experiment I, though this time we did not record ovarian and uterine structures following PRID insertion or plasma progesterone concentrations after PRID removal. Cyclicity at treatment and herd were registered as two classes of independent variables (absence of luteal structures or presence of at least one CL and Herd 1 or Herd $2)$. Treatment dates were used to assess the effects of season on subsequent reproductive performance. In our geographical region, there are only two clearly differentiated weather periods: warm (May to September) and cool (October to April) $[37,38]$.

Two binary logistic regression analyses were performed using estrous response after PRID removal or conception 28-34 days post $\mathrm{AI}$ as the dependent variables. The factors entered in the model as independent variables were herd, season of treatment, parity, treatment, milk production and days in milk at treatment, cyclicity at treatment, semen-providing bull and AI technician. For the dependent variable conception rate, the estrus response was added as an independent variable. Regression analyses were conducted according to the method of Hosmer and Lemeshow [39] using the logistic procedure of PASW Statistics for Windows Version 18.0 (SPSS). Significance was set at $\mathrm{P}<0.05$.

The effects of treatment on the interval (h) from PRID removal to estrus were analyzed as described in Experiment I for the interval from PRID removal to AI. In this case, only cows showing estrus were included in the analysis.

\section{Results}

Experiment I. Effects of the four different P4-based estrus synchronization protocols on follicular/luteal/endometrial dynamics

Mean milk production and number of lactations at the time of treatment were $40 \pm 8.4 \mathrm{~kg}$ and $2.5 \pm 0.2$ lactations, respectively (mean $\pm \mathrm{SD}$ ). Table 1 provides data on the effects of treatment for each variable. Cows receiving $\mathrm{GnRH}$ at the beginning of treatment (groups 2PGG and 2PGGE) showed a significantly higher ovulation rate after PRID insertion $(\mathrm{OV})$ and a lower rate of follicular structures larger than $10 \mathrm{~mm}$ on PRID removal (FO) than cows not receiving a first GnRH dose (groups $2 \mathrm{PGe}$ and $\mathrm{PGe})(\mathrm{P}<0.05)$. Parity, days in milk, milk production and cyclicity at treatment could not be related to $\mathrm{OV}$ or $\mathrm{FO}$.

Cows receiving the $\mathrm{PGe}$ treatment were inseminated a mean of $19 \mathrm{~h}$ earlier $(\mathrm{P}<0.01)$ than cows given the remaining treatments. Ovulating cows $(\mathrm{n}=16)$ were inseminated significantly $(\mathrm{P}<0.05)$ later $(88.5 \pm 1.5 \mathrm{~h})$ after PRID insertion than non-ovulating cows ( $\mathrm{n}$ $=24 ; 75 \pm 3.4 \mathrm{~h}$ ). Cows with follicular structures larger than $10 \mathrm{~mm}$ on PRID removal $(\mathrm{n}=30)$ were inseminated significantly $(\mathrm{P}<0.05)$ earlier $(77.6 \pm 2.9 \mathrm{~h})$ than the remaining cows $(\mathrm{n}=10 ; 88.8 \pm 1.9 \mathrm{~h})$.

Parity, days in milk, milk production, cyclicity at treatment onset and uterine indicators of estrus had no impact on the estrus detection rate. Uterine indicators of estrus were recorded in 36 cows, of which $23(63.9 \%)$ showed estrus, whereas 1 (25\%) of the 4 cows with no uterine indicators did show signs of estrus. No factors were related to the conception rate.

The maximal CL diameter recorded at AI was smaller than 12 mm. Plasma progesterone concentration decreases from PRID removal to AI were similar for all treatments and for cows with or without a CL. All cows showed plasma progesterone levels lower than $0.5 \mathrm{ng} / \mathrm{ml}$ at $\mathrm{AI}$. 
Table 1. Effects of the different treatments on each variable (Experiment I; $\mathrm{N}=40$ )

\begin{tabular}{lccccc}
\hline Treatment & $\begin{array}{c}\text { 2PGG } \\
(\mathrm{N}=12)\end{array}$ & $\begin{array}{c}\text { 2PGGe } \\
\mathrm{N}=11)\end{array}$ & $\begin{array}{c}2 \mathrm{PGe} \\
(\mathrm{N}=7)\end{array}$ & $\begin{array}{c}\text { PGe } \\
(\mathrm{N}=10)\end{array}$ & $\begin{array}{c}\text { Total } \\
(\mathrm{N}=40)\end{array}$ \\
& $\mathrm{N}(\%)$ & $\mathrm{N}(\%)$ & $\mathrm{N}(\%)$ & $\mathrm{N}(\%)$ & $\mathrm{N}(\%)$ \\
\hline Dependent variable* & & & & & \\
CY & $7(58.3)$ & $8(72.7)$ & $5(71.4)$ & $10(100)$ & $30(75)$ \\
OV & $7(58.3)^{\mathrm{a}}$ & $8(72.7)^{\mathrm{a}}$ & $1(14.3)^{\mathrm{b}}$ & $0(0)^{\mathrm{b}}$ & $16(40)$ \\
FD & $4(33.3)^{\mathrm{b}}$ & $7(63.3)$ & $3(42.9)$ & $1(10)$ & $15(37.5)$ \\
FO & $8(66.7)^{\mathrm{a}}$ & $5(45.5)^{\mathrm{a}}$ & $7(100)^{\mathrm{b}}$ & $10(100)^{\mathrm{b}}$ & $13(32.5)$ \\
ER & $6(50)$ & $7(63.6)$ & $2(42.9)$ & $8(80)$ & $24(60)$ \\
CL & $4(33.3)$ & $5(45.5)$ & $2(28.6)$ & $5(50)$ & $16(40)$ \\
UI & $10(83.3)$ & $10(90.9)$ & $7(100)$ & $9(90)$ & $36(90)$ \\
FS (mean $\pm \mathrm{SD})$ & $16 \pm 0.2$ & $19 \pm 0.2$ & $20 \pm 0.6$ & $20 \pm 0.6$ & $19 \pm 0.1$ \\
HO (mean $\pm \mathrm{SD})$ & $85 \pm 2.3^{\mathrm{c}}$ & $82.9 \pm 13.6^{\mathrm{c}}$ & $89.1 \pm 6.8^{\mathrm{c}}$ & $66 \pm 3.6^{\mathrm{d}}$ & $80.4 \pm 15$ \\
CR & $2(16.7)$ & $5(45.5)$ & $3(42.9)$ & $3(30)$ & $13(32.5)$ \\
\hline
\end{tabular}

* Values for each categorical variable with a different superscript differ significantly according to Tukey-Kramer tests $(\mathrm{P}<0.05)$. Values of the continuous variable $\mathrm{HO}$ with different superscripts differ significantly according to ANOVA and Tukey post-hoc tests $(\mathrm{P}<0.01)$. Dependent variables: $\mathrm{CY}$, cyclicity at treatment; OV, ovulation after PRID insertion; FD, follicular dynamics after PRID insertion (appearance or disappearance of a follicular structure larger than $10 \mathrm{~mm}$ before PRID removal); FO, presence of at least a follicular structure larger than $10 \mathrm{~mm}$ on PRID removal; ER, estrus detection rate after PRID removal; CL, presence of at least a CL at AI; UI, uterine indicators of estrus; FS, follicular size (diameter in $\mathrm{mm}$ ) of the largest follicle at AI; HO, hours from PRID removal to AI; CR, conception rate 28-34 days post AI. Treatments (all cows received a GnRH dose at AI; AI was performed at estrus/FTAI was performed $96 \mathrm{~h}$ after PRID removal): 2PGG: PRID for 5 days, GnRH on day $0, \mathrm{PGF}_{2 \alpha}$ on PRID removal and $24 \mathrm{~h}$ later. 2PGGe: PRID for 5 days, GnRH on day $0, \mathrm{PGF}_{2 \alpha}$ plus eCG on PRID removal and $\mathrm{PGF}_{2 \alpha} 24 \mathrm{~h}$ later. $2 \mathrm{PGe}$ PRID for 5 days, $\mathrm{PGF}_{2 \alpha}$ plus eCG on PRID removal and $\mathrm{PGF}_{2 \alpha} 24$ $\mathrm{h}$ later. PGe: PRID for 5 days, $\mathrm{PGF}_{2 \alpha}$ plus eCG on PRID removal.

Table 2. Effects of the different treatments on each variable (Experiment II; $\mathrm{N}=351$ )

\begin{tabular}{|c|c|c|c|c|c|}
\hline Treatment & $\begin{array}{c}2 \mathrm{PGG} \\
(\mathrm{N}=90) \\
\mathrm{N}(\%)\end{array}$ & $\begin{array}{c}\text { 2PGGe } \\
(\mathrm{N}=86) \\
\mathrm{N}(\%)\end{array}$ & $\begin{array}{c}2 \mathrm{PGe} \\
(\mathrm{N}=89) \\
\mathrm{N}(\%)\end{array}$ & $\begin{array}{c}\text { PGe } \\
(\mathrm{N}=86) \\
\mathrm{N}(\%)\end{array}$ & $\begin{array}{c}\text { Total } \\
(\mathrm{N}=351) \\
\mathrm{N}(\%)\end{array}$ \\
\hline \multicolumn{6}{|l|}{ Dependent variable* } \\
\hline $\mathrm{CY}$ & $53(58.9)$ & $50(58.1)$ & $48(53.9)$ & $48(55.8)$ & $199(56.7)$ \\
\hline ER & $42(46.6)^{a}$ & $45(52.3)^{\mathrm{a}}$ & $62(69.7)^{b}$ & $37(43)^{a}$ & $186(53)$ \\
\hline $\mathrm{HO}($ mean $\pm \mathrm{SD})$ & $70.3 \pm 11.2^{c}$ & $72.1 \pm 12.8^{\mathrm{c}}$ & $70.6 \pm 14^{c}$ & $64.8 \pm 10.9^{\mathrm{d}}$ & $69.5 \pm 12.3$ \\
\hline $\mathrm{CR}$ & $39(43.3)$ & $38(44.2)$ & $36(40.4)$ & $35(40.7)$ & $149(42.5)$ \\
\hline
\end{tabular}

* Values for each categorical variable with a different superscript differ significantly according to Tukey-Kramer tests (P $<0.05$ ). Values of the continuous variable $\mathrm{HO}$ with different superscripts differ significantly according to ANOVA and Tukey post-hoc tests $(\mathrm{P}<0.01)$. Dependent variables: $\mathrm{CY}$, cyclicity at treatment; ER, estrous response after PRID removal; HO, hours from PRID removal to estrus only in cows showing estrus; CR, conception rate 28-34 days post AI. Treatments (all cows received a GnRH dose at AI; AI was performed at estrus/FTAI was performed $96 \mathrm{~h}$ after PRID removal): 2PGG: PRID for 5 days, GnRH on day $0, \mathrm{PGF}_{2 \alpha}$ on PRID removal and $24 \mathrm{~h}$ later. $2 \mathrm{PGGe:} \mathrm{PRID} \mathrm{for} 5$ days, GnRH on day $0, \mathrm{PGF}_{2 \alpha}$ plus eCG on PRID removal and $\mathrm{PGF}_{2 \alpha} 24 \mathrm{~h}$ later. $2 \mathrm{PGe}$ : PRID for 5 days, $\mathrm{PGF}_{2 \alpha}$ plus eCG on PRID removal and $\mathrm{PGF}_{2 \alpha} 24$ h later. PGe: PRID for 5 days, PGF $_{2 \alpha}$ plus eCG on PRID removal.

Experiment II. Effects of the four different P4-based estrus synchronization protocols on estrus detection and the conception rate

Mean milk production and number of lactations at the time of treatment were $45 \pm 4.6 \mathrm{~kg}$ and $2.5 \pm 0.1$ lactations, respectively $($ mean \pm SD). Table 2 provides data on the treatment effects for each variable. Cows not given $\mathrm{GnRH}$ at the start of treatment but receiving a double dose of $\mathrm{PGF}_{2 \alpha}$ (group $2 \mathrm{PGe}$ ) showed a significantly higher estrous response than cows in the remaining treatments $(\mathrm{P}<0.05)$. Cows given the PGe treatment displayed estrus an average of $5 \mathrm{~h}$ earlier $(\mathrm{P}<0.01)$ than cows receiving the remaining treatments.
Based on the odds ratios (Table 3), cows with luteal activity at treatment were less likely (by a factor of 0.6) to show estrus than cows with no luteal activity $(\mathrm{P}=0.03)$. Primiparous cows were more likely (by a factor of 1.41) to show estrus than multiparous cows $(\mathrm{P}=0.001)$. Cows given the $2 \mathrm{PGe}$ treatment were more likely (by a factor of 2.21) to show estrus than cows receiving the remaining treatments $(\mathrm{P}=0.001)$.

No significant effects of the variables examined on the conception rate were identified by binary logistic regression. All treatments gave rise to a mean conception rate of $42.5 \%$. 
Table 3. Odds ratios of the variables included in the final logistic regression model for factors affecting the estrous response (Experiment II; $\mathrm{N}=351$ )

\begin{tabular}{llcccc}
\hline \multirow{2}{*}{ Factor } & \multicolumn{1}{c}{ Class } & $\mathrm{n}(\%$ estrous cows) & Odds ratio & $\begin{array}{c}95 \% \text { confidence } \\
\text { interval }\end{array}$ & $\mathrm{P}$ \\
\hline Luteal activity at treatment & No & $94 / 152(61.8 \%)$ & Reference & & \\
& Yes & $92 / 199(46.2 \%)$ & 0.6 & $0.4-0.92$ & 0.03 \\
\hline Parity & Multiparous & $113 / 229(49.3 \%)$ & Reference & & \\
& Primiparous & $73 / 122(59.8 \%)$ & 1.41 & $1.08-3.11$ & 0.001 \\
\hline Treatment & 2PGG & $42 / 90(46.6 \%)$ & Reference & & 0.133 \\
& 2PGGe & $45 / 86(52.3 \%)$ & 1.66 & $0.88-2.97$ & 0.001 \\
& 2PGe & $62 / 89(69.7 \%)$ & 2.21 & $1.5-4.31$ & 0.921 \\
\hline
\end{tabular}

Hosmer and Lemeshow goodness-of-fit test $=0.465 ; 6 \mathrm{df}, \mathrm{P}=0.028$. R2 Nagelkerke $=0.062$. Treatments: 2PGG: PRID for 5 days, GnRH on day 0, $\mathrm{PGF}_{2 \alpha}$ on PRID removal and $24 \mathrm{~h}$ later. 2PGGe: PRID for 5 days, GnRH on day $0, \mathrm{PGF}_{2 \alpha}$ plus eCG on PRID removal and PGF $_{2 \alpha} 24$ h later. 2PGe: PRID for 5 days, PGF $_{2 \alpha}$ plus eCG on PRID removal and PGF $2 \alpha 24$ later. PGe: PRID for 5 days, $\mathrm{PGF}_{2 \alpha}$ plus eCG on PRID removal.

\section{Discussion}

To the best of our knowledge, this study is the first to examine the estrous response and subsequent fertility of cows subjected to short (5-day) progesterone-based estrus synchronization protocols. Ovarian and endometrial dynamics from the start of treatment until AI were also assessed. Our findings indicate the good performance of all these protocols applied to high-producing dairy cows. Points to be highlighted were that cows receiving GnRH at treatment onset showed a greater likelihood of ovulation during the PRID insertion period and were less likely to have at least one follicular structure larger than $10 \mathrm{~mm}$ upon PRID removal than cows not receiving this initial GnRH dose. In addition, cyclicity at the time of treatment negatively affected the estrous response. The given treatment had impacts on both the estrous response and the time from PRID removal to estrus, but not on fertility. Collectively, our results suggest that the different combinations of hormones tested here lead to acceptable fertility and that the time from treatment to estrus could serve as a good guide for FTAI after a 5-day progesterone-based synchronization protocol.

Ovulation during the PRID insertion period (five days) is likely to yield a CL that is too young upon PRID removal. Although complete luteolysis at AI was observed in all cows (Table 1), the induced CL would have little chance to respond to the first prostaglandin dose $[40,41]$. It is known that treatment with a single $\mathrm{PGF}_{2 \alpha}$ dose results in partial luteolysis in cows with a CL younger than 5 days [42, 43], so a second prostaglandin dose $24 \mathrm{~h}$ later should complete luteolysis. This delayed luteolysis explains why cows subjected to the $2 \mathrm{PGG}$ and 2PGGe protocols showed a greater interval from PRID removal to estrus (Table 2) or AI (Table 1) compared with those subjected to the PGe protocol. Ovulation during PRID treatment was not recorded for the PGe protocol, which did not include a GnRH dose at PRID insertion or a second $\mathrm{PGF}_{2 \alpha}$ dose. Therefore, the $\mathrm{CL}$ of cows receiving PGe should be older than the CL of cows in the 2PGG and 2PGGe groups, and the condition of the CL might be the same as that in the $2 \mathrm{PGe}$ group, in which ovulation was only registered in a single cow. In these two groups, $\mathrm{PGe}$ and $2 \mathrm{PGe}$, luteolysis is likely completed earlier, and eCG likely favors earlier estrus. However, cows in the
2PGe group not given $\mathrm{GnRH}$ at the start of treatment but receiving a second PGF $2 \alpha$ dose showed an interval from PRID removal to estrus that was similar to those of animals in the 2PGG and 2PGGe groups (Table 2). Interestingly, the greatest estrous response was recorded in cows in the $2 \mathrm{PGe}$ group (Table 2). The second $\mathrm{PGF}_{2 \alpha}$ dose probably reduced progesterone level favoring estrous signs in cows maintaining luteal activity. This could explain both the higher estrous response compared with the remaining groups and the delayed interval from PRID removal to estrus compared with the PGe group.

Luteal activity at the time of treatment negatively affected the estrous response (Table 3). The presence of a CL at treatment probably hinders the development of a preovulatory follicle that is large enough to produce estrous signs [9]. This idea is supported by the fact that, in Experiment I, cows with follicular structures larger than $10 \mathrm{~mm}$ on PRID removal were inseminated earlier than the remaining cows and the fact that cows ovulating during the PRID insertion period (cows with an induced CL) were inseminated later than non-ovulating cows. However, the estrous response was not a factor affecting fertility in Experiment II. Since eCG with high FSH- and LH-like activity [44] was not included in all the protocols, GnRH at AI synchronized ovulation regardless of follicular diameter and estrous behavior.

The warm period of the year is usually the main factor negatively affecting estrous behavior [31], the estrous response to different synchronization protocols [16] and fertility $[2,3,38]$ in our region. Thus, P4 treatment probably reduced the effects of heat stress, and season did not emerge as a factor affecting the estrous response or fertility, reinforcing the results of our prior work on five-day P4-based protocols $[19,23]$. Primiparous cows showed a higher estrous response than their multiparous partners (Table 3), as has been extensively described [9].

The present findings show acceptable results of 5-day progesteronebased protocols for AI performed at estrus or for FTAI conducted $96 \mathrm{~h}$ after PRID removal in high-producing dairy cows. Although treatment affected both the estrous response and the interval from PRID removal to estrus, fertility was similar for all protocols. All protocols were able to overcome the negative effects of heat stress. 


\section{Acknowledgments}

The authors thank Ana Burton for assistance with the English translation.

\section{References}

1. Lucy MC. Reproductive loss in high-producing dairy cattle: where will it end? J Dairy Sci 2001; 84: 1277-1293. [Medline] [CrossRef]

2. López-Gatius F. Factors of a noninfectious nature affecting fertility after artificial insemination in lactating dairy cows. A review. Theriogenology 2012; 77: 1029-1041. [Medline] [CrossRef]

3. López-Gatius F. Is fertility declining in dairy cattle? A retrospective study in northeastern Spain. Theriogenology 2003; 60: 89-99. [Medline] [CrossRef]

4. López-Gatius F, García-Ispierto I, Santolaria P, Yániz J, Nogareda C, López-Béjar M. Screening for high fertility in high-producing dairy cows. Theriogenology 2006; 65 : 1678-1689. [Medline] [CrossRef]

5. García-Ispierto I, López-Gatius F, Santolaria P, Yániz JL, Nogareda C, López-Béjar M. Factors affecting the fertility of high producing dairy herds in northeastern Spain. Theriogenology 2007; 67: 632-638. [Medline] [CrossRef]

6. Windig JJ, Calus MPL, Veerkamp RF. Influence of herd environment on health and fertility and their relationship with milk production. J Dairy Sci 2005; 88: 335-347. [Medline] [CrossRef]

7. Calus MP, Windig JJ, Veerkamp RF. Associations among descriptors of herd management and phenotypic and genetic levels of health and fertility. $J$ Dairy Sci 2005; 88: 2178-2189. [Medline] [CrossRef]

8. Peter AT, Vos PLAM, Ambrose DJ. Postpartum anestrus in dairy cattle. Theriogenology 2009; 71: 1333-1342. [Medline] [CrossRef]

9. Roelofs J, López-Gatius F, Hunter RHF, van Eerdenburg FJCM, Hanzen C. When is a cow in estrus? Clinical and practical aspects. Theriogenology 2010; 74: 327-344. [Medline] [CrossRef]

10. Roche JF, Crowe MA, Boland MP. Postpartum anoestrus in dairy and beef cows. Anim Reprod Sci 1992; 28: 371-378. [CrossRef]

11. Rhodes FM, McDougall S, Burke CR, Verkerk GA, Macmillan KL. Invited review: Treatment of cows with an extended postpartum anestrous interval. J Dairy Sci 2003; 86: 1876-1894. [Medline] [CrossRef]

12. Yániz JL, Murugavel K, López-Gatius F. Recent developments in oestrous synchronization of postpartum dairy cows with and without ovarian disorders. Reprod Domest Anim 2004; 39: 86-93. [Medline] [CrossRef]

13. Macmillan KL. Recent advances in the synchronization of estrus and ovulation in dairy cows. J Reprod Dev 2010; 56(Suppl): S42-S47. [Medline] [CrossRef]

14. López-Gatius F, Santolaria P, Yániz J, Rutllant J, López-Béjar M. Persistent ovarian follicles in dairy cows: a therapeutic approach. Theriogenology 2001; 56: 649-659. [Medline] [CrossRef]

15. Lòpez-Gatius F, Murugavel K, Santolaria P, López-Béjar M, Yániz JL. Pregnancy rate after timed artificial insemination in early post-partum dairy cows after Ovsynch or specific synchronization protocols. J Vet Med A Physiol Pathol Clin Med 2004; 51: 33-38. [Medline] [CrossRef]

16. López-Gatius F, Mirzaei A, Santolaria P, Bech-Sàbat G, Nogareda C, García-Ispierto I, Hanzen C, Yániz JL. Factors affecting the response to the specific treatment of several forms of clinical anestrus in high producing dairy cows. Theriogenology 2008; 69: 1095-1103. [Medline] [CrossRef]

17. Lima FS, Ayres H, Favoreto MG, Bisinotto RS, Greco LF, Ribeiro ES, Baruselli PS, Risco CA, Thatcher WW, Santos JE. Effects of gonadotropin-releasing hormone at initiation of the 5-d timed artificial insemination (AI) program and timing of induction of ovulation relative to AI on ovarian dynamics and fertility of dairy heifers. $J$ Dairy Sci 2011; 94: 4997-5004. [Medline] [CrossRef]

18. Ribeiro ES, Monteiro APA, Lima FS, Ayres H, Bisinotto RS, Favoreto M, Greco LF, Marsola RS, Thatcher WW, Santos JEP. Effects of presynchronization and length of proestrus on fertility of grazing dairy cows subjected to a 5-day timed artificial insemination protocol. J Dairy Sci 2012; 95: 2513-2522. [Medline] [CrossRef]

19. Garcia-Ispierto I, Roselló MA, De Rensis F, López-Gatius F. A five-day progesterone plus eCG-based fixed-time AI protocol improves fertility over spontaneous estrus in high-producing dairy cows under heat stress. J Reprod Dev 2013; 59: 544-548. [Medline] [CrossRef]

20. Revah I, Butler WR. Prolonged dominance of follicles and reduced viability of bovine oocytes. J Reprod Fertil 1996; 106: 39-47. [Medline] [CrossRef]
21. Nation DP, Burke CR, Parton G, Stevenson R, Macmillan KL. Hormonal and ovarian responses to a 5-day progesterone treatment in anoestrous dairy cows in the third week post-partum. Anim Reprod Sci 2000; 63: 13-25. [Medline] [CrossRef]

22. Cerri RLA, Rutigliano HM, Chebel RC, Santos JE. Period of dominance of the ovulatory follicle influences embryo quality in lactating dairy cows. Reproduction 2009; 137 813-823. [Medline] [CrossRef]

23. Garcia-Ispierto I, López-Gatius F. Effects of different five-day progesterone-based fixed-time AI protocols on follicular/luteal dynamics and fertility in dairy cows. $J$ Reprod Dev 2014; 60: 426-432. [Medline] [CrossRef]

24. López-Gatius F, Yániz J, Madriles-Helm D. Effects of body condition score and score change on the reproductive performance of dairy cows: a meta-analysis. Theriogenology 2003; 59: 801-812. [Medline] [CrossRef]

25. Roche JR, Friggens NC, Kay JK, Fisher MW, Stafford KJ, Berry DP. Invited review: Body condition score and its association with dairy cow productivity, health, and welfare. J Dairy Sci 2009; 92: 5769-5801. [Medline] [CrossRef]

26. López-Gatius F, García-Ispierto I. Ultrasound and endocrine findings that help to assess the risk of late embryo/early foetal loss by non-infectious cause in dairy cattle. Reprod Domest Anim 2010; 45(Suppl 3): 15-24. [Medline] [CrossRef]

27. López-Helguera I, López-Gatius F, Garcia-Ispierto I. The influence of genital tract status in postpartum period on the subsequent reproductive performance in high producing dairy cows. Theriogenology 2012; 77: 1334-1342. [Medline] [CrossRef]

28. Hanzen CH, Bascon F, Theron L, López-Gatius F. Ovarian cysts in cattle Part 1: Definitions, symptoms and diagnostic. Ann Med Vet 2007; 151: 247-256.

29. López-Gatius F, Labèrnia J, Santolaria P, López-Béjar M, Rutllant J. Effect of reproductive disorders previous to conception on pregnancy attrition in dairy cows Theriogenology 1996; 46: 643-648. [Medline] [CrossRef]

30. Hanzen C, Bascon F, Theron L, López-Gatius F. Ovarian cysts in cattle 3. Therapeutic aspects. Ann Med Vet 2008; 152: 103-115.

31. López-Gatius F, Santolaria P, Mundet I, Yániz JL. Walking activity at estrus and subsequent fertility in dairy cows. Theriogenology 2005; 63: 1419-1429. [Medline] [CrossRef

32. López-Gatius F, Camón-Urgel J. Increase of pregnancy rate in dairy cattle after preovulatory follicle palpation and deep cornual insemination. Theriogenology 1988; 29: 1099-1103. [Medline] [CrossRef]

33. López-Gatius F, Camón-Urgel J. Confirmation of estrus rates by palpation per rectum of genital organs in normal repeat dairy cows. Zentralbl Veterinarmed A 1991; 38: 553-556. [Medline] [CrossRef]

34. López-Gatius F. Site of semen deposition in cattle: a review. Theriogenology 2000; 53: 1407-1414. [Medline] [CrossRef]

35. Knopf L, Kastelic JP, Schallenberger E, Ginther OJ. Ovarian follicular dynamics in heifers: test of two-wave hypothesis by ultrasonically monitoring individual follicles Domest Anim Endocrinol 1989; 6: 111-119. [Medline] [CrossRef]

36. Pierson RA, Ginther OJ. Ultrasonographic appearance of the bovine uterus during the estrous cycle. J Am Vet Med Assoc 1987; 190: 995-1001. [Medline]

37. Labèrnia J, López-Gatius F, Santolaria P, Hanzen C, Laurent Y, Houtain JY. Influence of calving season on the interactions among reproductive disorders of dairy cows. Anim Sci 1998; 67: 387-393. [CrossRef]

38. García-Ispierto I, López-Gatius F, Bech-Sabat G, Santolaria P, Yániz JL, Nogareda C, De Rensis F, López-Béjar M. Climate factors affecting conception rate of high producing dairy cows in northeastern Spain. Theriogenology 2007; 67: 1379-1385. [Medline] [CrossRef]

39. Hosmer DW, Lemeshow S. Applied Logistic Regression. New York: Wiley; 1989.

40. Tsai SJ, Wiltbank MC. Prostaglandin F2alpha regulates distinct physiological changes in early and mid-cycle bovine corpora lutea. Biol Reprod 1998; 58: 346-352. [Medline] [CrossRef]

41. Miyamoto A, Shirasuna K, Wijayagunawardane MPB, Watanabe S, Hayashi M, Yamamoto D, Matsui M, Acosta TJ. Blood flow: a key regulatory component of corpu luteum function in the cow. Domest Anim Endocrinol 2005; 29: 329-339. [Medline] [CrossRef]

42. Cuervo-Arango J, García-Roselló E, García-Muñoz A, Valldecabres-Torres $\mathbf{X}$, Martínez-Ros P, González-Bulnes A. The effect of a single high dose of PGF2 $\alpha$ administered to dairy cattle 3.5 days after ovulation on luteal function, morphology, and follicular dynamics. Theriogenology 2011; 76: 1736-1743. [Medline] [CrossRef]

43. Valldecabres-Torres X, García-Roselló E, García-Muñoz A, Cuervo-Arango J. Effects of d-cloprostenol dose and corpus luteum age on ovulation, luteal function, and morphology in nonlactating dairy cows with early corpora lutea. J Dairy Sci 2012; 95: 4389-4395. [Medline] [CrossRef]

44. De Rensis F, López-Gatius F. Use of equine chorionic gonadotropin to control reproduction of the dairy cow: a review. Reprod Domest Anim 2014; 49: 177-182. [Medline] [CrossRef] 